\title{
Biocontrol Potential of Chitin and Chitosan Extracted from Black Soldier Fly Pupal Exuviae against Bacterial Wilt of Tomato
}

\author{
Violah Jepkogei Kemboi ${ }^{1}$, Carolyne Kipkoech ${ }^{2, *}$, Moses Njire ${ }^{1}$, Samuel Were ${ }^{1}$, Mevin Kiprotich Lagat ${ }^{1}$, \\ Francis Ndwiga ${ }^{1}$, John Mwibanda Wesonga ${ }^{3}$ and Chrysantus Mbi Tanga ${ }^{4}$ (D)
}

1 Department of Botany, Jomo Kenyatta University of Agriculture and Technology, Nairobi P.O. Box 62000-02000, Kenya; violahkemboi42@gmail.com (V.J.K.); mnjire@jkuat.ac.ke (M.N.); samaringo@gmail.com (S.W.); mlagat237@gmail.com (M.K.L.); irerifin@gmail.com (F.N.)

2 Department of Food and Nutritional Sciences, Jomo Kenyatta University of Agriculture and Technology, Nairobi P.O. Box 62000-02000, Kenya

3 Department of Horticulture and Food Security, Jomo Kenyatta University of Agriculture and Technology, Nairobi P.O. Box 62000-02000, Kenya; jwesonga@agr.jkuat.ac.ke

4 International Centre of Insect Physiology and Ecology (ICIPE), Nairobi P.O. Box 30772-00100, Kenya; ctanga@icipe.org

* Correspondence: kipkoechcarolyne@gmail.com

Citation: Kemboi, V.J.; Kipkoech, C.; Njire, M.; Were, S.; Lagat, M.K.; Ndwiga, F.; Wesonga, J.M.; Tanga, C.M. Biocontrol Potential of Chitin and Chitosan Extracted from Black Soldier Fly Pupal Exuviae against Bacterial Wilt of Tomato. Microorganisms 2022, 10, 165. https://doi.org/10.3390/ microorganisms10010165

Academic Editor: Maurizio Ciani

Received: 10 November 2021 Accepted: 12 December 2021 Published: 13 January 2022

Publisher's Note: MDPI stays neutral with regard to jurisdictional claims in published maps and institutional affiliations.

Copyright: (c) 2022 by the authors. Licensee MDPI, Basel, Switzerland. This article is an open access article distributed under the terms and conditions of the Creative Commons Attribution (CC BY) license (https:// creativecommons.org/licenses/by/ $4.0 /)$.

\begin{abstract}
Globally, Ralstonia solanacearum (Smith) is ranked one of the most destructive bacterial pathogens inducing rapid and fatal wilting symptoms on tomatoes. Yield losses on tomatoes vary from 0 to $91 \%$ and most control measures are unaffordable to resource-poor farmers. This study investigated the antimicrobial activities of chitin and chitosan extracted from black soldier fly (BSF) pupal exuviae against $R$. solanacearum. Morphological, biochemical, and molecular techniques were used to isolate and characterize $R$. solanacearum for in vitro pathogenicity test using disc diffusion technique. Our results revealed that BSF chitosan significantly inhibited the growth of $R$. solanacearum when compared to treatments without chitosan. However, there was no significant difference in the antibacterial activities between BSF and commercial chitosan against $R$. solanacearum. Soil amended with BSF-chitin and chitosan demonstrated a reduction in bacterial wilt disease incidence by $30.31 \%$ and $34.95 \%$, respectively. Whereas, disease severity was reduced by $22.57 \%$ and $23.66 \%$, when inoculated tomato plants were subjected to soil amended with BSF chitin and chitosan, respectively. These findings have demonstrated that BSF pupal shells are an attractive renewable raw material for the recovery of valuable products (chitin and chitosan) with promising ability as a new type of eco-friendly control measure against bacterial wilt caused by R. solanacearum. Further studies should explore integrated pest management options that integrate multiple components including insectbased chitin and chitosan to manage bacterial wilt diseases, contributing significantly to increased tomato production worldwide.
\end{abstract}

Keywords: tomato bacterial wilt disease; insect pupal shell; organic soil amendment; integrated pest management; Ralstonia solanacearum

\section{Introduction}

The bacteria Ralstonia solanacearum (Smith) is a soil-borne plant pathogen that affects mainly solanaceous plants and some non-solanaceous plants [1]. They are Gram-negative, short rod, strict aerobe, non-spore-forming, motile bacteria. Molecular characterization of $R$. solanacearum strains based on sequence analysis of internal spacer (ITS) region has resulted in four phylotypes divisions [2]. Ralstonia solanacearum has been reported to be the causal agent of bacterial wilt disease in over 200 host plant species belonging to 50 plant families [3]. These bacteria infect plants from planting media through root injuries caused either by mechanical, insect, or nematode damage [4]. The bacteria has been reported to 
colonize the xylem vessels of the plants leading to massive destruction through the blockage of the water transportation system [4]. This causes the plant to develop characteristic wilting signs and symptoms that include yellowing of leaves, stunted plant growth, and sudden death [5]. This characteristic dead process caused by the R. solanacearum is referred to as vascular wilt disease and the disease has been ranked as the second most important bacterial pathogen worldwide [6].

Remarkably, it has been widely documented as one of the most destructive pathogens identified to date due to its ability to induce rapid and fatal wilting symptoms in infected host plant species with severe economic impact [7]. However, the direct yield losses caused by $R$. solanacearum vary widely according to the host, cultivar, climate, soil type, cropping pattern, and strain [6]. Previous studies have highlighted yield losses ranging between 0 and $91 \%, 33-90 \%, 10-30 \%, 80-100 \%$, and up to $20 \%$ for tomato, potato, tobacco, banana, and groundnut, respectively [6,8]. Many studies have associated the difficulties of controlling $R$. solanacearum with its ability to grow endophytically, survive in soil, especially in the deeper layers, travel along the water, and its relationship with weeds [6]. This observation is consistent with the report by [9], who reported the management of $R$. solanacearum through the use of disease-resistant cultivars, crop rotation, and field sanitation have been largely unsuccessful.

Although synthetic bactericides have shown success, they are associated with air, underground water, soil pollution, residual toxicity effects [10], loss of biodiversity [11], and development of pathogen resistance [12]. Thus, there has been increased interest in the use of alternative management strategies for $R$. solanacearum including the use of potential biological control agents such as antagonistic microorganisms [13]. However, the use of these microorganisms is associated with challenges relating to storage time [14]. There is, therefore, a need for the development of alternative control agents such as plant extracts [15] and biopolymers such as chitin and its derivatives [16] for use in the management of plant disease. Chitin is a natural polysaccharide occurring as a structural component of living organisms such as insects, fungi, and crustaceans [17]. Chitosan refers to an $\mathrm{N}$-acetyl D-glucosamine polysaccharide usually obtained through deacetylation of chitin using sodium hydroxide or chitinase enzymes. In agriculture, chitin derivatives are ranked first in the list of basic compounds approved in the European Union (EU) for their application in organic agriculture and integrated pest management systems [18]. Chitosan has unique biological properties such as biodegradability, biocompatibility, non-toxicity, and antimicrobial activities [19]. Due to these advantages, they have been applied in various fields such as in the food industry, agriculture, medicine, wastewater treatment, paper, and cosmetics industries [20]. Conventionally, organisms such as crabs, shrimps, krill, lobsters, and waste from the seafood industry have been used as the commercial source of chitin. Additionally, research has shown that insects such as beetles, grasshopper [21], and black soldier fly can be a potential source of chitin production.

Black soldier fly (BSF; Hermetia illucens) is a known resource insect native to the tropical regions of America and South America but recently it is distributed in almost all parts of the world. This fly feeds naturally in decaying organic matter and the process converts biomass nutrients into its biomass thus it constituent a means of recycling waste in the environment. BSF has also been shown as a valuable source of proteins, lipids, fats, and other minerals. Due to this, BSF rearing technology is currently increasing mainly for the production of poultry, pig and fish feeds, and biodiesel. Additionally, BSF has been reported as a potential source of chitin. Although chitin and chitosan from black soldier fly have been shown to have similar properties to those from other sources, there is no information and research attention on their antibacterial activities against severe plant diseases such as tomato bacterial wilt. Hence, this study aimed at investigating the antimicrobial activities of chitin and chitosan extracted from black soldier fly pupal exuviae waste against $R$. solanacearum to guide their introduction into the integrated pest management toolbox to manage bacterial wilt diseases and contribute to increased tomato production worldwide. 


\section{Materials and Methods}

\subsection{Study Site}

This study was conducted at Jomo Kenyatta University of Agriculture and Technology (JKUAT), Juja Kiambu County $\left(1.0891^{\circ} \mathrm{S}, 37.0105^{\circ} \mathrm{E}\right.$, altitude of 1400 asl). In vitro and field tests were done at the Department of Botany laboratory and Department of Horticulture and Food Security greenhouse, respectively. The pupal exuviae from which both chitin and chitosan were extracted was obtained from the BSF mass production facility at the Animal Rearing and Containment Unit (ARCU) at the International Centre of Insect Physiology and Ecology (icipe), Nairobi, Kenya.

\subsection{Soil Sample Collection and Isolation of Ralstonia solanacearum}

Soil samples were randomly collected from tomato growing fields that had dead tomato plants and those depicting wilting symptoms at Jomo Kenyatta University of Agriculture and Technology (JKUAT). Blocks were earmarked for the trial then divided into plots. Three independent plots were selected then subdivided into numbered units. Three units per plot were randomly selected and soils collected (in triplicates) by digging around the plant roots at $30 \mathrm{~cm}$ depth using a sterile jembe. Ten grams of the sampled soil was suspended in $100 \mathrm{~mL}$ of sterile distilled water then agitated for $10 \mathrm{~min}$ on a mechanical shaker. Serial dilution was performed by transferring $1 \mathrm{~mL}$ of the suspension into $9 \mathrm{~mL}$ of sterile distilled water in test tubes to dilution factor $10^{-6}$. Plating was done by pipetting and spreading $0.1 \mathrm{~mL}$ of the suspension from each dilution tube onto sterile Triphenyl tetrazolium chloride (TZC) agar plates. The plates were then incubated at $37^{\circ} \mathrm{C}$ for $24 \mathrm{~h}$ after which bacterial growth was measured by counting colonies of $R$. solanacearum and documented.

\subsection{Cultural Characterization}

Typical cultural characteristics of $R$. solanacearum were determined using $24 \mathrm{~h}$ old cultures grown at $37^{\circ} \mathrm{C}$ on TZC gar according to the procedure done by [22]. The fluidal, irregularly round colonies with white margins and light pink centers were considered to be $R$. solanacearum colonies $[23,24]$ and were sub-cultured to obtain pure cultures for subsequent use.

\subsubsection{Morphological Characterization}

Gram staining of pure cultures of the $R$. solanacearum was done following the procedure described by [25]. This involved spreading a loopful of the colonies on a glass slide and heatfixing on a very low flame. Aqueous crystal violet solution was spread over the smear and left for $30 \mathrm{~s}$ then washed with running tap water for one minute. It was then flooded with iodine and left for one minute, rinsed with tap water, then decolorized with $95 \%$ ethanol until clear runoff. After washing, the smear was counter-stained with safranin for $30 \mathrm{~s}$, washed with tap water, dried, and observed at a magnification at $\times 100$ using oil immersion. Pink short rod-shaped cells were considered a positive test for R. solanacearum [26].

\subsubsection{Biochemical Characterization}

The bacterial solubility in $3 \% \mathrm{KOH}$ was examined to eliminate any possible confusion of the bacterial pathogens that cause wilting in tomatoes as described by Khasabulli et al. (2017). The pure culture of the pathogen was picked using a sterile wire loop and placed on the glass slide containing a drop of $3 \% \mathrm{KOH}$ solution. It was stirred for about $10 \mathrm{~s}$ then raised for a few centimeters from the slide while observing for mucoid/slime threads. The formation of a viscous solution or slime thread indicated a positive test (KOH soluble). A catalase test was done as described by Khasabulli et al. (2017), whereby a loopful of fresh bacterial culture of $R$. solanacearum was mixed with a drop of $3 \%$ hydrogen peroxide $\left(\mathrm{H}_{2} \mathrm{O}_{2}\right)$ on a glass slide and observed for the production of gas bubbles. An observation of effervescence suggested a positive test $[23,25]$. 
A gas production test for the pure cultures of isolated $R$. solanacearum was conducted according to the procedure done by Pawaskar et al. (2014). Sterile nutrient broth with $2 \%$ glucose in test tubes containing inverted Durham tubes was used. The test tubes were inoculated with $0.5 \mathrm{~mL}$ of bacterial suspension and incubated at $37^{\circ} \mathrm{C}$ for $24 \mathrm{~h}$. The presence of air bubbles in the inverted Durham tube was an indication of gas production hence considered a positive test. The ability of $R$. solanacearum isolate to hydrolyze starch in nutrient agar was tested according to the procedure done by Pawaskar et al. (2014). The bacterial cultures of $R$. solanacearum were inoculated and spread on the center of sterile nutrient agar plates containing $0.02 \%$ starch then incubated at $37^{\circ} \mathrm{C}$ for $24 \mathrm{~h}$. After incubating, the plates were flooded with Lugol's iodine. A clear zone around bacterial culture suggested a positive test $[25,27]$.

\subsubsection{Molecular Characterization}

The genomic DNA was extracted using Quick-DNA ${ }^{\mathrm{TM}}$ Fungal/Bacterial Miniprep kit (Zymo Research Corp, Irvine, CA, USA). A pure culture of $R$. solanacearum was sub-cultured on Casamino acids Peptone Glucose (CPGA) plates and incubated overnight then used for extraction of DNA based on the manufacturer's instructions. The extracted DNA was run under $1 \%$ agarose gel electrophoresis and visualized on an ultraviolet Transilluminator (UVT-20 SML model). Multiplex PCR was performed for phylotype identification and confirmation of the isolated $R$. solanacearum diseased plants from JKUAT fields using phylotype-specific primers as described by Fegan and Prior (2005). The reaction was carried out in a total volume of $25 \mu \mathrm{L}$ reaction containing: One Taq $2 X$ Master mix, phylotypespecific forward primers; Nmult:21:1F, Nmult:21:2F, Nmult:22: lnF, Nmult:23:AF, reverse primer Nmult:22:RR, DNA template, and Taq DNA polymerase. Amplifications were done in an Eppendorf AG, 22331 Hamburg, Germany thermocycler using the following conditions: initial denaturation at $94{ }^{\circ} \mathrm{C}$ for $3 \mathrm{~min}, 35$ cycles of denaturation at $94{ }^{\circ} \mathrm{C}$ for $30 \mathrm{~s}$, annealing at $55^{\circ} \mathrm{C}$ for $30 \mathrm{~s}$, extension at $72{ }^{\circ} \mathrm{C}$ for $30 \mathrm{~s}$, and a final extension step at $72{ }^{\circ} \mathrm{C}$ for $7 \mathrm{~min}$. The amplified PCR products were run through electrophoresis on $1 \%(w / v)$ agarose gel and visualized on a UV transilluminator [28].

\subsection{Pathogenicity Test}

A pathogenicity test was conducted on one-month-old healthy tomato seedlings (Prostar F1) using $R$. solanacearum from the International Centre of Potato Research (CIP) and those isolated from JKUAT fields. The soil drench method was used for inoculation of the plants with the pathogen according to the procedure by Kariuki (2020). The seedlings were transplanted onto plastic pots containing autoclaved cocopeat mixed with Hoagland's solution. The plants were left in the medium for three days to let them stabilize. After three days of stabilization in the medium, the seedlings were injured on the stems just above the growth media surface and the roots using a sterile scalpel blade. Turbidity of bacterial suspension was adjusted to $0.5 \mathrm{McF}$ arland equivalents then $10 \mathrm{~mL}$ drenched on the injured stems and roots using a sterile syringe. A set of transplanted seedlings drenched with sterile distilled water served as the control. Each treatment consisted of 10 plants one per pot and the experiment was done in triplicates. The plants were then monitored for bacterial wilt symptoms in the greenhouse under natural sunlight conditions. Plants with at least one wilted leaf were considered diseased. After the development and appearance of wilting symptoms, the pathogen was reisolated on TZC media and re-identified using cultural, morphological, biochemical, and molecular methods [29].

\subsection{Extraction of Chitin and Chitosan}

Chitin and chitosan were extracted from the BSF pupal exuviae using chemical methods as described by Kaya et al. (2015). The pupal exuviae were sorted, washed thoroughly with tap water, and rinsed twice with distilled water, sun-dried, and ground into a fine powder using a blender. The obtained pupal exuviae powder was first demineralized by treating $100 \mathrm{~g}$ of the powder with $1000 \mathrm{~mL}$ of $1 \mathrm{M}$ hydrochloric acid then boiled for 
two hours to remove all the minerals. The demineralized material was then washed with distilled water until a neutral $\mathrm{pH}$ was achieved, then filtered and dried in an oven at $60{ }^{\circ} \mathrm{C}$ for $6 \mathrm{~h}$. The dried demineralized powder weighing $100 \mathrm{~g}$ was then treated with $1000 \mathrm{~mL}$ of $1 \mathrm{M}$ sodium hydroxide $(\mathrm{NaOH})$ then boiled for $4 \mathrm{~h}$ to remove proteins. The extracted chitin material was washed thoroughly with distilled water until it attained a neutral $\mathrm{pH}$ and dried in an oven at $60{ }^{\circ} \mathrm{C}$ for $6 \mathrm{~h}$. Thereafter, the chitin was further processed to produce chitosan as described by Kaya et al. (2015) but with slight variations. One hundred grams of dried chitin was refluxed in $1000 \mathrm{~mL}$ of $40 \% \mathrm{NaOH}$ then boiled for $8 \mathrm{~h}$ with continuous stirring. The obtained product was washed thoroughly with distilled water to a neutral $\mathrm{pH}$ then dried in an oven at $60^{\circ} \mathrm{C}$. Chitosan (CHT) extracts weighing $0.5,1,2.5$, and $5 \mathrm{~g}$ were dissolved in $100 \mathrm{~mL}$ of $1 \%(v / v)$ acetic acid solution separately to obtain different concentrations of CHT $(w / v)$. Following the dissolution of chitosan in acetic acid, it was sterilized by autoclaving at $121{ }^{\circ} \mathrm{C}$ for $15 \mathrm{~min}$ and stored at $4{ }^{\circ} \mathrm{C}$ for later use $[30,31]$.

\subsection{Antimicrobial Effects of BSF Chitosan on Ralstonia solanacearum}

Antimicrobial activities of BSF chitosan against $R$. solanacearum were tested using disc diffusion [32]. Pure cultures of R. solanacearum were sub-cultured overnight at $37^{\circ} \mathrm{C}$ on casamino peptone glucose (CPG) agar media. Bacterial colonies from the plates were suspended in sterile normal saline and adjusted to obtain an equivalent of $0.5 \mathrm{McFarland}$. then pipetted onto $20 \mathrm{~mL}$ of Mueller Hilton Agar plates. L-form glass spreader was sterilized by passing over a flame and used to spread the bacterial suspension over the Agar plates. Sterile Whatman's filter paper discs of $6 \mathrm{~mm}$ diameter were soaked in different concentrations $(0,0.5,1,2.5$, and $5 \%)$ of sterilized BSF chitosan. Chitosan-soaked discs were air-dried then gently picked using sterile forceps and placed on the surface of inoculated agar plates at equidistant positions. Filter paper discs soaked in sterile distilled water were used as the negative control. The plates were incubated at $37^{\circ} \mathrm{C}$ for $24 \mathrm{~h}$ The inhibition zones were measured in millimeters and average inhibition zones were calculated for the three replicates. The "control treatment" consisted of different concentrations of commercial chitosan $(0,0.5,1,2.5$, and 5\%) and eight different antibiotic discs: Ampicillin (25 $\mu \mathrm{g})$, Tetracycline $(100 \mu \mathrm{g})$, Nitrofurantoin $(200 \mathrm{mcg})$, Nalidixic acid (30 $\mu \mathrm{g})$, Streptomycin $(25 \mu \mathrm{g})$, Sulphamethoxazole $(200 \mu \mathrm{g})$, and Cotrimoxazole $(25 \mu \mathrm{g})$ [33].

\subsection{Effects of BSF Chitosan on Ralstonia solanacearum Symptom Expression in Tomato}

Tomato seeds (Prostar F1 from Simlaw Seeds Company, Nairobi, Kenya) were grown in seed propagating units for 30 days. The seedlings were then transplanted onto plastic pots containing $200 \mathrm{~g}$ of sterile growth media (cocopeat) and $20 \mathrm{~g}$ of BSF-derived chitin and chitosan separately. Three days after transplanting $50 \mathrm{~mL}$ of Hoagland's solution was added to the transplanted plants. Fourteen days after transplanting, the plants were inoculated by drenching $10 \mathrm{~mL}$ of $0.5 \mathrm{McF}$ arland suspension of $R$. solanacearum. The plants were injured using sterile scalpel around roots and on stem slightly above the growth media surface. The pathogen was drenched around the injured surface using a sterile syringe. Seedlings transplanted into sterile growth media devoid of chitin or chitosan extracts and inoculated with $R$. solanacearum served as the positive control. Other seedlings transplanted onto growth media without chitin or chitosan and not inoculated with $R$. solanacearum bacterial suspension served as the negative control. The experiments were replicated three times and arranged in a completely randomized design in the greenhouse under natural light conditions. The plants were irrigated after every $12 \mathrm{~h}$ and other standard agronomic practices were observed to ensure that plants were free from any form of stress.

Bacterial wilt disease incidence (DI) was monitored daily for 1 month after pathogen inoculation. Plants with wilted leaves were recorded as diseased plants. The percent disease incidence was calculated using the formula by Kempe and Sequeira (1983):

$$
\% \mathrm{DI}=\frac{n}{N} \times 100
$$


where $n=$ Number of wilted leaves per plant, $N=$ total number of leaves.

Bacterial wilt disease severity was evaluated based on the scale (0-5) of Kempe and Sequeira (1983) where $0=$ no symptoms; $1=1-25 \%$ leaves wilted; $2=26-50 \%$ leaves wilted; $3=51-75 \%$ leaves wilted; $4=$ more than $75 \%$ but less than $100 \%$ of leaves wilted; $5=$ all leaves wilted and plant death.

The percent disease severity (DS) was calculated using the formula [34]:

$$
\% \text { DS }=[\Sigma(n i \times v i) \div(\mathrm{V} \times \mathrm{N})]
$$

where $\mathrm{ni}=$ number of plants with the respective disease rating; $\mathrm{vi}=$ disease rating; $\mathrm{V}=$ the highest disease rating; and $\mathrm{N}=$ the number of plants observed

\subsection{Data Collection and Analysis}

Data on cultural, biochemical, and molecular characterization were collected by observation, and the results were recorded on excel sheets. The data on antimicrobial activity was collected by measuring clear zones of inhibition around each disc on each plate of each test organism. All experimental data were expressed as means \pm standard error. Data analysis was done using Stata SE-64 2011 statistics software and means separated using the Bonferroni range test. The difference in mean inhibition zone was done using a one-way analysis of variance, and the difference was considered significant at $p \leq 0.05$.

\section{Results and Discussion}

\subsection{Characterization of Ralstonia solanacearum}

Kelzman's tetrazolium chloride (TZC) media-enabled successful isolation of $R$. solanacearum from the soil sample collected from the JKUAT farm and differentiation of virulent and avirulent strains. Most colonies on the observed plates appeared as large, fluidal irregularly round white with a pale red to the pink center on TZC media hence as per Balabel (2018) they were virulent [35] (Figure 1).

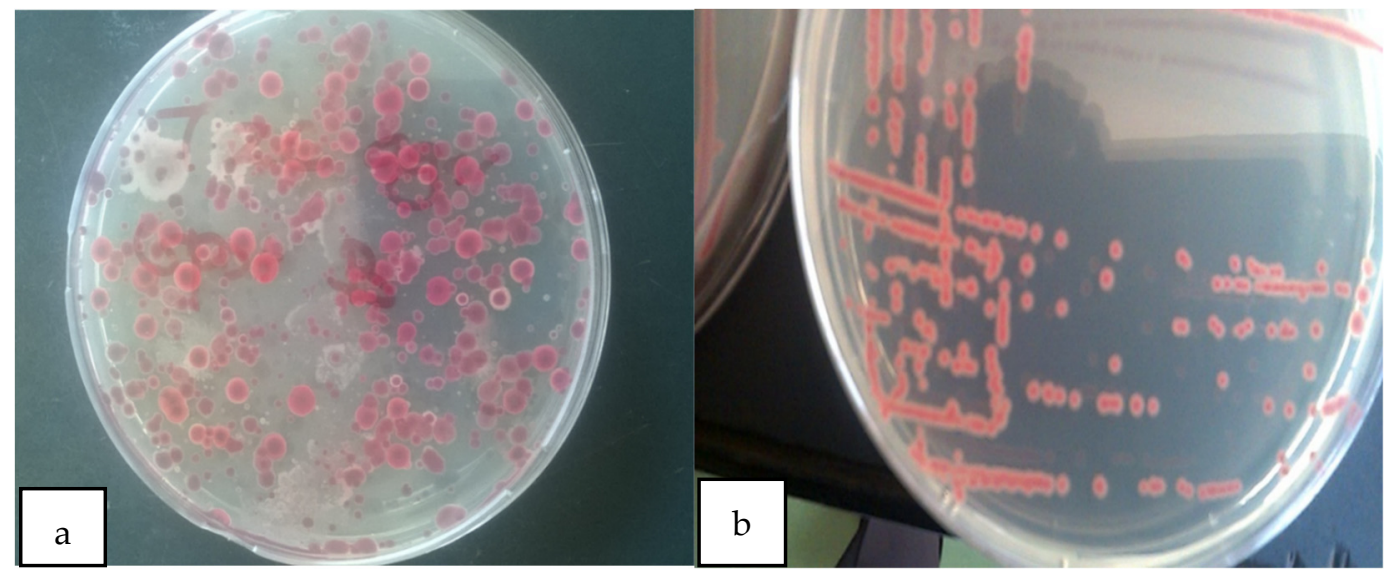

Figure 1. (a) Mixed colonies of virulent and avirulent $R$. solanacearum; (b) pure colonies of virulent $R$ solanacearum.

The observation of Gram staining reaction done on the colonies of $R$. solanacearum isolates showed pink small rod-shaped cells under the microscope at $\times 100$ magnification (Table 1). These Gram staining reaction observations are in line with those reported by Mutimawurugo et al. (2019) where all isolated R. solanacearum from three regions in Rwanda were Gram-negative short rods. This is because R. solanacearum is a Gram-negative rod-shaped bacterium and that all plant pathogenic bacteria are usually Gram-negative except Streptomyces and Clavibacter [23,36]. 
Table 1. Gram staining and biochemical reaction tests for the isolated R. solanacearum.

\begin{tabular}{cc}
\hline Test & Observation \\
\hline Gram stain reaction test & - \\
Potassium Hydroxide solubility test & + \\
Catalase test & + \\
Gas production test & - \\
Starch hydrolysis test &
\end{tabular}

There was a formation of viscous thread following $\mathrm{KOH}$ tests on all the isolates. The observations conform to that reported by Teli et al. (2018) where the formation of mucoid or slime thread was observed when the bacterial suspension of $R$. solanacearum was raised from a glass slide containing $3 \% \mathrm{KOH}$ [9]. The formation of viscous, mucoid, or slime thread is due to the outer membrane of Gram-negative bacteria being readily disrupted when exposed to $3 \% \mathrm{KOH}$ releasing the viscous DNA [23]. The potassium hydroxide solubility test is an important test for confirmation of the Gram-negative test and helps in differentiating $R$. solanacearum from other wilt-causing microorganisms such as Fusarium [22].

The catalase test showed that all the isolates were able to produce gas bubbles when they were mixed with a drop of $3 \%$ hydrogen peroxide hence were considered as catalase positive. These findings conform to those found by Khasabulli et al. (2017), whereby $R$. solanacearum isolated from the Maseno region was catalase-positive [23]. The gas production mixed with hydrogen peroxide is due to the ability of $R$. solanacearum to produce catalase enzyme. Catalase enzyme protects the bacteria from the toxic effects of hydrogen peroxide by catalyzing its breakdown into water and oxygen [37]. The production of gas bubbles also shows that the bacteria are aerobic or facultative anaerobe. All isolates of $R$. solanacearum were able to produce gas from glucose after $24 \mathrm{~h}$ of incubation hence was considered positive for the gas test. This was also observed by Khasabulli et al. (2017), when they experimented on $R$. solanacearum, they found that $R$. solanacearum was able to produce gas within $18 \mathrm{~h}$ of incubation. The isolates under investigation were not able to hydrolyze starch. This was a result of the absence of clear zones on the agar after incubation, confirming that the isolates were for $R$. solanacearum. The findings were similar to the results of the studies conducted by Sharma and Singh (2019) and Bawari and Narendrappa (2019) who found that $R$. solanacearum was unable to hydrolyze starch [22,24].

Based on the molecular characterization of the samples, it was clear that the bands observed were in the range of $372 \mathrm{bp}$, confirming that the sample was $R$. solanacearum (Figure 2). The findings are concurring with that of Paudel et al. (2020) who observed that $R$. solanacearum has four distinct phylotypes. Phylotype I generates $144 \mathrm{bp}$ for primers Nmult21:1F/Nmult22: RR, phylotype II generates 372 bp for primers Nmult21:2F/Nmult22: RR, phylotype III generates 91 bp for primers Nmult23: AF/Nmult22: RR phylotype IV generates $213 \mathrm{bp}$ for primers Nmult22:InF/Nmult22:RR [2,38]. Based on phylotype groups, the $R$. solanacearum species complex is divided into subspecies for instance phylotype I and phylotype III are classified as R. pseudosolanacearum phylotype II as $R$. solanacearum and phylotype IV as Ralstonia syzygii [39]. Therefore, the findings of this study confirm that phylotype II, which is R. solanacearum species is present in the JKUAT farm. 


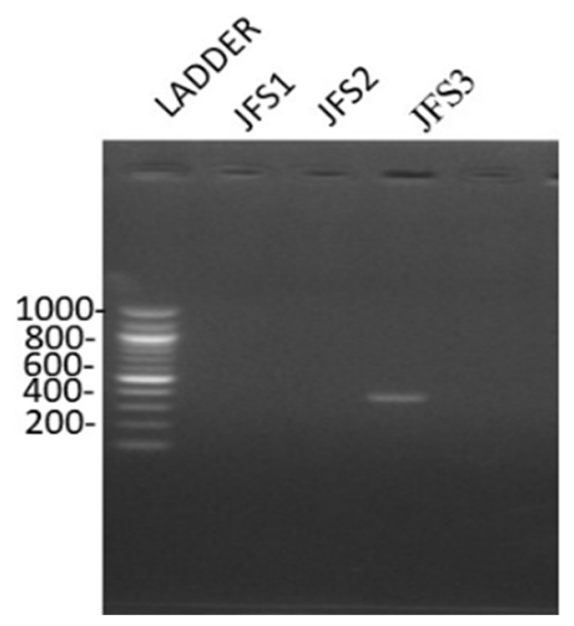

Figure 2. R. solanacearum DNA bands as observed under UV-transilluminator.

\subsection{Pathogenicity Test}

The $R$. solanacearum was confirmed to cause bacterial wilt in tomato plants. Bacterial wilt symptoms including yellowing of the younger lower leaves, dropping of the leaves, and wilting of the plants' leaves and stem during daytime were observed two weeks after transplanting and inoculation (Figure 3). One month later, there was the formation of brown discoloration of vascular bundles in the stem above the soil layer. Additionally, the infected plants showed milky white substance streaming from the cross-sectional cuttings of the stem a sign of bacteria in the vascular tissues [23].

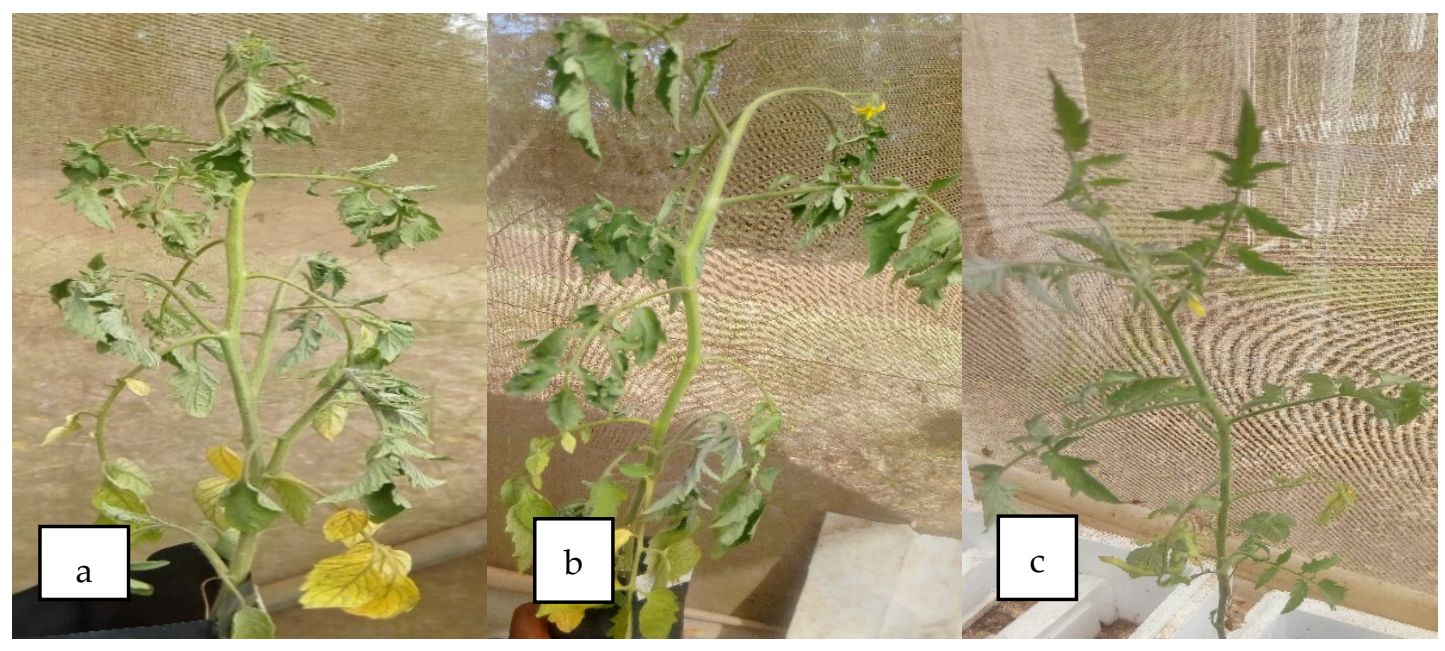

Figure 3. Tomato plants showing bacterial wilting symptoms: (a) plant inoculated with $R$. solanacearum isolated from JKUAT farm, (b) plant inoculated with $R$. solanacearum obtained from International Potato Centre (CIP), and (c) plant not inoculated.

Diameters of zones of inhibitions produced by BSF-based pupal exuviae chitosan and commercial chitosan showed no statistically significant differences. However, there were statistically significant differences in the antibacterial activities against the $R$. solanacearum among the various treatments (Table 2). 
Table 2. Antimicrobial effects of BSF, commercial chitosan, and antibiotic discs against R. solanacearum.

\begin{tabular}{ccc}
\hline Treatment & $\begin{array}{c}\text { Means of Inhibition } \\
\text { Standard Error of the Mean })\end{array}$ & $p$-Value \\
\hline Sterile distilled water & $0 \pm 2.35^{\mathrm{d}}$ & $<0.001$ \\
$1 \%$ acetic acid without chitosan & $11.67 \pm 2.35^{\mathrm{b}}$ & 0.002 \\
BSF chitosan & $19.83 \pm 1.17^{\mathrm{a}}$ & 0.004 \\
Commercial chitosan & $18.5 \pm 1.17^{\mathrm{a}}$ & $<0.001$ \\
Nalidixic acid $(30 \mu \mathrm{g})$ & $26 \pm 2.349153^{\mathrm{e}}$ & 0.002 \\
Streptomycin $(25 \mu \mathrm{g})$ & $10.67 \pm 2.35^{\mathrm{b}}$ & 0.041 \\
Sulphamethoxazole $(200 \mu \mathrm{g})$ & $16.67 \pm 2.35^{\mathrm{c}}$ & 0.021 \\
Cotrimoxazole $(25 \mu \mathrm{g})$ & $21 \pm 2.35^{\mathrm{c}}$ & 0.021 \\
Gentamycin $(10 \mu \mathrm{g})$ & $20 \pm 2.35^{\mathrm{c}}$ & $<0.001$ \\
Ampicillin $(25 \mu \mathrm{g})$ & $0 \pm 2.34^{\mathrm{d}}$ & $<0.001$ \\
Tetracycline $(100 \mu \mathrm{g})$ & $20 \pm 2.34^{\mathrm{c}}$ & $<0.001$ \\
Nitrofurantoin $(200 \mu \mathrm{g})$ & $15.67 \pm 2.34^{\mathrm{c}}$ & 0.002 \\
\hline
\end{tabular}

Data shown are means of three replications. Means with different letters (superscript) are significantly different at $p \leq 0.05$.

The exact mechanisms of antimicrobial activities of BSF-based pupal exuviae chitosan are not well known. However, there are some proposed modes of action reported in previous studies. The most known mechanism involved in antimicrobial activities is attributed to the presence of amino groups on the chitosan structure that causes electrostatic interaction between their positive charges and negative charges of lipopolysaccharide on the bacterial cell membrane [40]. The electrostatic interaction has been known to disrupt the cell wall and cell membrane thus interfering with its permeability. Another postulate is that chitosan anionic charges (amino group) bind to the negatively charged phosphate groups on DNA and amino acids of the proteins thus inactivating or inhibiting messenger RNA (mRNA) and protein synthesis [41]. Chitosan can also inhibit bacterial growth by chelating essential nutrients and metals [42].

Tomato plants treated with BSF-based pupal exuviae chitin and chitosan showed a reduction in disease incidence by $30.31 \%$ and $34.95 \%$, respectively, whereas the disease severity was reduced by $22.57 \%$ and $23.66 \%$, respectively, compared to the control (Table 3 ).

Table 3. Bacterial wilt disease incidence (DI) and disease severity (DS).

\begin{tabular}{|c|c|c|}
\hline Treatment & $\begin{array}{l}\text { Mean \% Disease Incidence } \pm \text { Standard } \\
\text { Error of the Mean }\end{array}$ & $\begin{array}{l}\text { Mean \% Disease Severity } \pm \text { Standard } \\
\text { Error of Mean }\end{array}$ \\
\hline \multirow{3}{*}{$\begin{array}{l}\text { BSF-based pupal exuviae chitin } \\
\text { BSF-based pupal exuviae chitosan } \\
\text { Positive control }\end{array}$} & $30.31 \pm 1.36^{a}$ & $22.57 \pm 2.01^{\mathrm{a}}$ \\
\hline & $34.95 \pm 0.60^{\mathrm{a}}$ & $23.66 \pm 1.15^{a}$ \\
\hline & $44.78 \pm 1.56^{\mathrm{b}}$ & $36.95 \pm 1.49^{b}$ \\
\hline \multirow[t]{3}{*}{$p$-values } & $<0.001$ & $<0.001$ \\
\hline & \multicolumn{2}{|c|}{$\begin{array}{l}\text { Data shown are means of three replications. Means in a column followed by the same letter are not significantly } \\
\text { different at } p \leq 0.05 \text {. }\end{array}$} \\
\hline & \multicolumn{2}{|c|}{$\begin{array}{l}\text { These findings are in agreement with those reported by Algam et al. (2016) where } \\
\text { they revealed the application of chitosan from shrimps through soil drenching reduced } \\
\text { wilting incidence by } 72 \% \text { in tomatoes. Similarly, chitin and chitosan-based polymers } \\
\text { showed a reduction in disease severity in cabbage and strawberry plants after being } \\
\text { challenged with Alternaria brassicicola and Colletotrichum fructicola in a study carried out } \\
\text { by Parada et al. (2018), reduced incidence of Fusarium wilt disease in tomato plants } \\
\text { (Malerba \& Cerana, 2018), and enhanced defense against Meloidogyne javanica in tomato } \\
\text { plants [14,43-45]. Tomato plants uninoculated with } R \text {. solanacearum did not show wilting } \\
\text { symptoms (Figure 4). There was no significant difference in bacterial wilt disease incidence } \\
\text { and severity between BSF-based pupal exuviae chitin and chitosan. }\end{array}$} \\
\hline
\end{tabular}




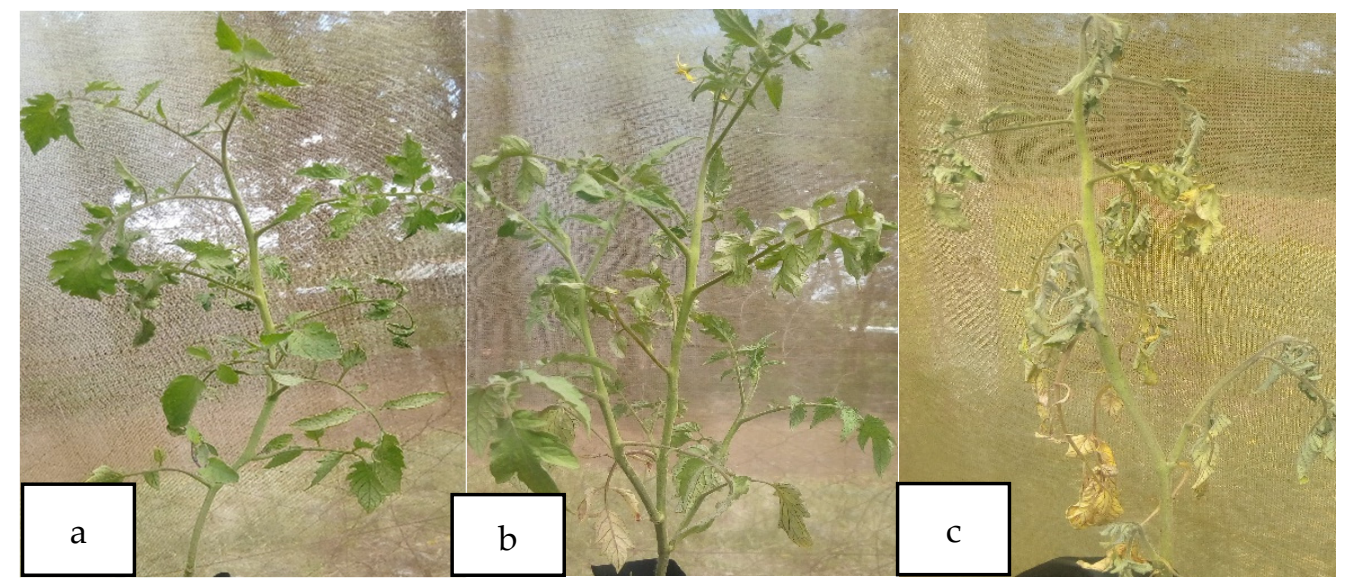

Figure 4. Wilting symptoms in (a) BSF-based pupal exuviae chitosan treated plant, (b) BSF-based pupal exuviae chitin treated plant, and (c) non-treated plant.

The reduction of wilting disease incidence and severity by BSF-based pupal exuviae chitin and chitosan is attributed to proposed mechanisms that include direct antibacterial activity through cell lysis [41], and the formation of a mechanical barrier that protects against pathogens [46]. They can trigger plant defense responses and activate different pathways which increase the plant's resistance to diseases [12]. In certain instances, they can stimulate hypersensitive responses in plants primarily around the infection site that results in programmed cell death. The hypersensitive response can be followed by systemic responses that include the synthesis and build-up of pathogenesis-related proteins, phytoalexins, and phenolic compounds. The systemic response can also modulate the activity of key enzymes such as chitinase, catalase, and superoxide dismutase peroxides that are involved in metabolic pathways in the defense response [41]. Chitosan showed better results than chitin which may have been caused by the deacetylation and solubility of chitosan. Recent studies have shown chitosan's ability to increase photosynthesis, plant tolerance to stress, and expression of defense genes which helps the plant to better fight infection [47].

\section{Conclusions}

The early detection of $R$. solanacearum belonging to phylotype II is essential for preventing its introduction into new areas due to its ability to survive for prolonged periods in soil, water, and plant materials. The avoidance of tomato losses due to this pathogen would significantly contribute to increased crop production in the country. Although, many researchers have managed bacterial wilt with biological, physical, and chemical methods and/or with cultural practices; this study provides the first evidence on the efficiency of BSF-based pupal exuviae chitin and chitosan antimicrobial activities and potential to protect against $R$. solanacearum in tomato plants. The remarkable reduction of bacterial wilt disease incidence by $30.31 \%$ and $34.95 \%$ in cocopeat amended with chitin and chitosan, respectively, isolated from BSF pupal exuviae demonstrated these shells are an attractive renewable raw material for the recovery of valuable product with promising ability as a new type of eco-friendly control measure against bacterial wilt, $R$. solanacearum. From the findings of this study, chitosan showed better results than chitin hence use of chitosan is the best approach. Further studies should explore the effects of direct application of the BSF pupal exuviae on $R$. solanacearum in soil and their integration into integrated pest management strategies that involve multiple components to manage bacterial wilt diseases, thus significantly contributing to increased tomato production worldwide. Our primary goal is to contribute to environmentally safe, sustainable, and increased tomato production for income and food security. However, research attention to cost-benefit analyses is indispensable in the short, middle, and long term. 
Author Contributions: V.J.K., C.K., M.K.L., S.W., M.N., J.M.W. and C.M.T., conceived the experiment; M.N., M.K.L., S.W., F.N., V.J.K., C.K. and C.M.T., designed the experiment; V.J.K., M.K.L. and C.K., investigation; C.M.T. resources; V.J.K., writing—original draft preparation; V.J.K., M.K.L., J.M.W., C.K. and C.M.T. writing-review and editing; V.J.K., C.K. and C.M.T., visualization; S.W., M.N., J.M.W. and C.K., supervision; S.W., F.N., M.N., J.M.W., C.K. and C.M.T., project administration; C.M.T., funding acquisition. All authors have read and agreed to the published version of the manuscript.

Funding: Financial support for this research was provided by the Bill \& Melinda Gates Foundation (INV-032416), the Curt Bergfors Foundation Food Planet Prize Award, the Canadian International Development Research Centre (IDRC), the Australian Centre for International Agricultural Research (ACIAR) (INSFEED—Phase 2: Cultivate Grant No: 108866-001), the Norwegian Agency for Development Cooperation, the Section for Research, Innovation, and Higher Education grant number RAF-3058 KEN-18/0005 (CAP-Africa), the Netherlands Organization for Scientific Research, WOTRO Science for Global Development (NWO-WOTRO) (ILIPA-W 08.250.202), and the Rockefeller Foundation (SiPFeed-Grant No: 2018 FOD 009). We also gratefully acknowledge the support of the International Centre of Insect Physiology and Ecology (icipe)'s core funding provided by the United Kingdom's Foreign, Commonwealth, and Development Office (FCDO); the Swedish International Development Cooperation Agency (Sida); the Swiss Agency for Development and Cooperation (SDC); the Federal Democratic Republic of Ethiopia; and the Government of the Republic of Kenya. The funders had no role in the study design, the data collection and analysis, the decision to publish, or the preparation of the manuscript; therefore, the views expressed herein do not necessarily reflect the official opinion of the donors.

Institutional Review Board Statement: Not applicable.

Informed Consent Statement: Not applicable.

Data Availability Statement: Not applicable.

Acknowledgments: The authors would like to acknowledge the support of Jomo Kenyatta University lab technicians and the JKUAT horticultural student association (HOSA).

Conflicts of Interest: The authors declare that there is no conflict of interest regarding this work.

\section{References}

1. Chandrashekara, K.; Kumar, M.P.; Saroja, S. Aggressiveness of Ralstonia solanacearum isolates on tomato. J. Exp. Sci. 2012, 3, 5-9.

2. Fegan, M.; Prior, P. How complex is the Ralstonia solanacearum species complex. Bact. Wilt Dis. Ralstonia Solanacearum Species Complex 2005, 1, 449-461.

3. Tahat, M.M.; Sijam, K. Ralstoina solanacearum: The bacterial wilt causal agent. Asian J. Plant Sci. 2010, 9, 385. [CrossRef]

4. Iraboneye, N.; Charimbu, M.K.; Mungai, N.W. Effect of Canola and Compound Fertilizer on Potato (Solanum Tuberosum L.) Bacterial Wilt Management. Eur. J. Agric. Food Sci. 2021, 3, 28-38. [CrossRef]

5. Ahing, F.A.; Wid, N. Extraction and characterization of chitosan from shrimp shell waste in Sabah. Trans. Sci. Technol. 2016, 3, 227-237.

6. Nion, Y.A.; Toyota, K. Recent trends in control methods for bacterial wilt diseases caused by Ralstonia solanacearum. Microbes Environ. 2015, 30, ME14144.

7. Campos, M.D.; Felix, M.d.R.; Patanita, M.; Materatski, P.; Varanda, C. High throughput sequencing unravels tomato-pathogen interactions towards a sustainable plant breeding. Hortic. Res. 2021, 8, 171. [CrossRef] [PubMed]

8. Elphinstone, J.G. The current bacterial wilt situation: A global overview. In Bacterial Wilt Disease And The Ralstonia Solanacearum Species Complex; American Phytopathological Society (APS Press): St. Paul, MN, USA, 2005; pp. 9-28.

9. Teli, K.; Shweta, H.; Kumar, M.P.; Kunduru, B.; Shekar, B.C. Isolation, identification and molecular characterization of Ralstonia solanacerum isolates collected from Southern Karnataka. J. Appl. Nat. Sci. 2018, 10, 886-893. [CrossRef]

10. Hassan, O.; Chang, T. Chitosan for eco-friendly control of plant disease. Asian J. Plant Pathol. 2017, 11, 53-70. [CrossRef]

11. Fan, Z.; Qin, Y.; Liu, S.; Xing, R.; Yu, H.; Chen, X.; Li, K.; Li, R.; Wang, X.; Li, P. The bioactivity of new chitin oligosaccharide dithiocarbamate derivatives evaluated against nematode disease (Meloidogyne incognita). Carbohydr. Polym. 2019, $224,115155$. [CrossRef] [PubMed]

12. Malerba, M.; Cerana, R. Recent applications of chitin-and chitosan-based polymers in plants. Polymers 2019, 11, 839. [CrossRef]

13. Chamedjeu, R.R. Prospecting for Biological Control Agents against Ralstonia Solanacearum in Potato. Ph.D. Thesis, Jkuat-Pausti, Juja, Kenya, 2018.

14. Algam, S.; Xie, G.; Li, B.; Yu, S.; Su, T.; Larsen, J. Effects of Paenibacillus strains and chitosan on plant growth promotion and control of Ralstonia wilt in tomato. J. Plant Pathol. 2010, 92, 593-600.

15. Buyela, D.K. Profiling and Pathogenicity of Ralstonia Solanacearum Disease of Tomato And It's Control Using Senna Didymobotrya and Moringa Oleifera Plant Extracts in Maseno (Kenya). Ph.D. Thesis, Maseno University, Kisumu, Kenya, 2017. 
16. Gitahi, D.W. Evaluation of Knowledge and Practices of Managing CITRUS Pests and Diseases and the Willingness to Pay for an Integrated Pest Management Strategy in Selected Counties in Kenya. Ph.D. Thesis, Egerton University, Njoro, Kenya, 2018.

17. Muzzarelli, R.A. Chitin; Elsevier: Amsterdam, The Netherlands, 2013.

18. Rajestary, R.; Landi, L.; Romanazzi, G. Chitosan and postharvest decay of fresh fruit: Meta-analysis of disease control and antimicrobial and eliciting activities. Compr. Rev. Food Sci. Food Saf. 2021, 20, 563-582. [CrossRef]

19. Jana, S.; Jana, S. Functional Chitosan: Drug Delivery and Biomedical Applications; Springer Nature: Berlin/Heidelberg, Germany, 2020.

20. Aranaz, I.; Acosta, N.; Civera, C.; Elorza, B.; Mingo, J.; Castro, C.; Gandía, M.D.1.L.; Heras Caballero, A. Cosmetics and cosmeceutical applications of chitin, chitosan and their derivatives. Polymers 2018, 10, 213. [CrossRef]

21. Kipkoech, C.; Kinyuru, J.N.; Imathiu, S.; Meyer-Rochow, V.B.; Roos, N. Invitro Study Of Cricket Chitosan's Potential As A Prebiotic And A Promoter Of Probiotic Microorganisms To Control Pathogenic Bacteria In The Human Gut. Foods 2021, 10, 2310. [CrossRef]

22. Sharma, D.; Singh, Y. Characterization of Ralstonia solanacearum isolates using biochemical, cultural, molecular methods and pathogenicity tests. J. Pharmacogn. Phytochem. 2019, 8, 2884-2889.

23. Khasabulli, B.D.; Musyimi, D.M.; Miruka, D.M.; Opande, G.T.; Jeruto, P. Isolation and characterisation of Ralstonia solanacearum strains of tomato wilt disease from Maseno, Kenya. J. Asian Sci. Res. 2017, 7, 404-420. [CrossRef]

24. Bawari, M.R.; Narendrappa, T. Cultural, biochemical and physiological studies of Ralstonia solanacearum causing wilt of brinjal. J. Pharmacogn. Phytochem. 2019, 8, 2042-2044.

25. Pawaskar, J.; Joshi, M.; Navathe, S.; Agale, R. Physiological and biochemical characters of ralstonia solanacearum. Int. J. Res. Agric. Sci. 2014, 1, 2348-3997.

26. Hossain, M.; Iqbal, A. Production and characterization of chitosan from shrimp waste. J. Bangladesh Agric. Univ. 2014, 12, 153-160. [CrossRef]

27. Kones, C.; Mwajita, M.; Kariuki, L.; Kiirika, L.; Kavoo, A. Isolation and characterization of rhizospheric microorganisms from bacterial wilt endemic areas in Kenya. Afr. J. Microbiol. Res. 2020, 14, 349-360.

28. Kiirika, L.M.; Stahl, F.; Wydra, K. Phenotypic and molecular characterization of resistance induction by single and combined application of chitosan and silicon in tomato against Ralstonia solanacearum. Physiol. Mol. Plant Pathol. 2013, 81, 1-12. [CrossRef]

29. Kariuki, C. Evaluation of Bacillus and Trichoderma Species for Biological Control of Bacterial Wilt Caused by Ralstonia Solanacearum in Tomato. Ph.D. Thesis, University of Nairobi, Nairobi, Kenya, 2020.

30. Kaya, M.; Erdogan, S.; Mol, A.; Baran, T. Comparison of chitin structures isolated from seven Orthoptera species. Int. J. Biol. Macromol. 2015, 72, 797-805. [CrossRef]

31. Kaya, M.; Baublys, V.; Šatkauskienè, I.; Akyuz, B.; Bulut, E.; Tubelytè, V. First chitin extraction from Plumatella repens (Bryozoa) with comparison to chitins of insect and fungal origin. Int. J. Biol. Macromol. 2015, 79, 126-132. [CrossRef]

32. Spirescu, V.A.; Chircov, C.; Grumezescu, A.M.; Vasile, B.Ș.; Andronescu, E. Inorganic Nanoparticles and Composite Films for Antimicrobial Therapies. Int. J. Mol. Sci. 2021, 22, 4595. [CrossRef]

33. Khameneh, B.; Eskin, N.; Iranshahy, M.; Fazly Bazzaz, B.S. Phytochemicals: A Promising Weapon in the Arsenal against Antibiotic-Resistant Bacteria. Antibiotics 2021, 10, 1044. [CrossRef]

34. Kempe, J.; Sequeira, L. Biological control of bacterial wilt of potatoes: Attempts to induce resistance by treating tubers with bacteria. Plant Dis. 1983, 67, 499-503. [CrossRef]

35. Ibrahim, Y.E.; Balabel, N.M.; Saleh, A.A.; Farag, N.S. Determination of differences in Ralstonia solanacearum phylotype II, sequevar 1 forms as related to their colony characteristics on Kelman medium and pathogenesis. J. Plant Pathol. 2020, 102, 59-66. [CrossRef]

36. Mutimawurugo, M.; Wagara, I.; Muhinyuza, J.; Ogweno, J. Virulence and characterization of isolates of potato bacterial wilt caused by Ralstonia solanacearum (Smith) in Rwanda. Afr. J. Agric. Res. 2019, 14, 311-320.

37. Tondo, M.L.; de Pedro-Jové, R.; Vandecaveye, A.; Piskulic, L.; Orellano, E.G.; Valls, M. KatE from the bacterial plant pathogen Ralstonia solanacearum is a monofunctional catalase controlled by HrpG that plays a major role in bacterial survival to hydrogen peroxide. Front. Plant Sci. 2020, 11, 1156. [CrossRef]

38. Paudel, S.; Dobhal, S.; Alvarez, A.M.; Arif, M. Taxonomy and Phylogenetic Research on Ralstonia solanacearum Species Complex: A Complex Pathogen with Extraordinary Economic Consequences. Pathogens 2020, 9, 886. [CrossRef]

39. Choi, C.H.; Lee, J.S.; Lee, Y.C.; Park, T.I.; Lee, J.C. Acinetobacter baumannii invades epithelial cells and outer membrane protein A mediates interactions with epithelial cells. BMC Microbiol. 2008, 8, 216. [CrossRef]

40. Morin-Crini, N.; Lichtfouse, E.; Torri, G.; Crini, G. Applications of chitosan in food, pharmaceuticals, medicine, cosmetics, agriculture, textiles, pulp and paper, biotechnology, and environmental chemistry. Environ. Chem. Lett. 2019, 17, 1667-1692. [CrossRef]

41. Kumaraswamy, R.; Kumari, S.; Choudhary, R.C.; Pal, A.; Raliya, R.; Biswas, P.; Saharan, V. Engineered chitosan based nanomaterials: Bioactivities, mechanisms and perspectives in plant protection and growth. Int. J. Biol. Macromol. 2018, 113, 494-506. [CrossRef]

42. Riaz Rajoka, M.S.; Mehwish, H.M.; Wu, Y.; Zhao, L.; Arfat, Y.; Majeed, K.; Anwaar, S. Chitin/chitosan derivatives and their interactions with microorganisms: A comprehensive review and future perspectives. Crit. Rev. Biotechnol. 2020, 40, 365-379. [CrossRef] 
43. Mota, L.C.; dos Santos, M.A. Chitin and chitosan on Meloidogyne javanica management and on chitinase activity in tomato plants. Trop. Plant Pathol. 2016, 41, 84-90. [CrossRef]

44. Parada, R.Y.; Egusa, M.; Aklog, Y.F.; Miura, C.; Ifuku, S.; Kaminaka, H. Optimization of nanofibrillation degree of chitin for induction of plant disease resistance: Elicitor activity and systemic resistance induced by chitin nanofiber in cabbage and strawberry. Int. J. Biol. Macromol. 2018, 118, 2185-2192. [CrossRef]

45. Malerba, M.; Cerana, R. Recent advances of chitosan applications in plants. Polymers 2018, 10, 118. [CrossRef] [PubMed]

46. Singh, A.; Gairola, K.; Upadhyay, V.; Kumar, J. Chitosan: An elicitor and antimicrobial Bio-resource in plant protection. Agric. Rev. 2018, 39, 163-168. [CrossRef]

47. Shahrajabian, M.H.; Chaski, C.; Polyzos, N.; Tzortzakis, N.; Petropoulos, S.A. Sustainable Agriculture Systems in Vegetable Production Using Chitin and Chitosan as Plant Biostimulants. Biomolecules 2021, 11, 819. [CrossRef] [PubMed] 